Однією $з$ особливостей представленої технології компаративного аналізу є спостереження над автентичним текстом культури як емоційно насиченого i максимально наповненого унікальним ціннісним змістом, що значною мірою мінімізує обсяг часу, відведеного на вивчення дисциплін нормативної частини професійної науково-предметної підготовки майбутніх учителів філологічних спеціальностей виключно за підручниками, які містять понятійно-фактичну інформацію й орієнтовані на одну несуперечливу авторську концепцію.

Пропозицією $\epsilon$ організація роботи 3 першоджерелами соціокультурної інформації, метою якої є розвиток культури читання, педагогічна підтримка студентів у їхньому самовизначенні у просторі соціокультурних цінностей.

Отже, діалектика соціокультурного i фахового полягає в тому, що загальнокультурний розвиток особистості зумовлює вибір професії педагога i підготовку до її здійснення. У подальшому сам цей вибір і безпосередня педагогічна діяльність визначають шляхи культурного розвитку фахівця. Розуміння соціокультурних знань як функціонально необхідних учителеві будь-якої фахової спеціалізації, визнання дидактичної компетентності вчителя філологічних спеціальностей чинником розвитку учнів завдяки вираженим критеріям професійної значимості й наявності механізмів впливу, надає підстави стверджувати, що культурологічну підготовку вчителя варто розглядати як провідний складник його педагогічної освіти.

На подальший розгляд заслуговує розроблення компаративних методик лінгвістичного аналізу тексту у змісті підготовки майбутніх філологів, зокремавідповідно до жанрової специфіки (мініатюра, гумореска / усмішка; рубаї; аннали (літописи); сонет; притча; епістола тощо) в соціокультурному контексті.

\title{
Література
}

1. Гончаренко С. У. Український педагогічний словник / [авт-уклад. С. У. Гончаренко]. - К. : Либідь, 1997. - 367 с. 2. Енциклопедія освіти : [гол. ред. В. Г. Кремень]. - К. : Юрінком Інтер, 2008. - 1040 с. З. Жила С. В. Теорія і практика вивчення української літератури у взаємозв'язках із різними видами мистецтв у старших класах загальноосвітньої школи : дис. ... доктора пед. наук; 13.00 .02 / Жила Світлана Олексіївна. - К., 2004. - 575 с. 4. Кузьмина Н. В. Акмеологическая теория повышения качества подготовки специалистов образования/ Нина Васильевна Кузьмина. - М. : Исслед. центр проблем качества подготовки специалистов, 2001. 144 с. 5. Лингвистический энциклопедический словарь / гл. ред. В. Н. Ярцева. - М. : Сов. Энциклопедия, 1990. - 685 с. 6. Философский словарь / под ред. И. Т. Фролова. [5-е изд.]. - М. : Политиздат, 1987. - 590 с. 7. Шевнюк О. Л. Теорія і практика культурологічної освіти майбутніх учителів у вищій школі : дис. ... доктора пед. наук; 13.00.04 / Шевнюк Олена Леонідівна. - К., 2004. - 473 с.

\section{СЕМІОТИЧНИЙ ПЦХІД У ПРОФЕСІЙНІЙ ПЦГОТОВЦ МАЙБУТНІХ УЧИТЕЛІВ МУЗИЧНОГО МИСТЕЦТВА ДО ВОКАЛЬНО-ПЕДАГОГІЧНОЇ ДІЯЛЬНОСТІ}

Овчаренко Н. А. Семіотичний підхід у професійній підготовці майбутніх учителів музичного мистецтва до вокально-педагогічної діяльності.

У статті розглядається актуальна проблема реалізації семіотичного підходу у професійній підготовці майбутніх учителів музичного мистецтва. Здійснено аналіз науково-теоретичного досвіду щодо визначення базових понять дослідження та 
обгрунтовано теоретичні аспекти семіотичного підходу у професійній підготовці майбутніх учителів музичного мистецтва.

Ключові слова: семіотика, семіотичний підхід, майбутній учитель музичного мистецтва.

Овчаренко Н. А. Семиотический подход в профессиональной подготовке будущих учителей музыкального искусства к вокально-педагогической деятельности.

В статье рассматривается актуальная проблема реализации семиотического подхода к профессиональной подготовке будущего учителя музыкального искусства. Проанализирован научно-теоретический опыт относительно определения базовых понятий исследования и обоснованы теоретические аспекты семиотического подхода в профессиональной подготовке будущих учителей музыкального искусства.

Ключевые слова: семиотика, семиотический подход, будущий учитель музыкального искусства.

Ovcharenko N. A. The semioticapproach to professional training of the future teacher on music art to vocal pedagogical activity

Actual problem of applying semioticapproach to professional training of the future teacher on music art is discovered in this article. Scientific theoretic experience was analyzed relatively definition of basic terms of exploration and the theoretic aspects of semiotic approach in professional training of future teachers on music art were basided.

Key words: semiotics, semiotics approach, future musical art teacher.

У професійній підготовці майбутніх учителів музичного мистецтва до вокальнопедагогічної діяльності є необхідним усвідомлення цінності і перетворювального впливу самого вокального мистецтва на особистість фахівця. Розв'язання такого завдання можливе завдяки реалізації семіотичного підходу до багатоаспектної i багатогранної проблеми смислу художнього твору та його усвідомлення, що надає змогу поглибити й наповнити новим змістом професійну підготовку вчителя музичного мистецтва до вокально-педагогічної діяльності.

Дослідження семіотичного підходу в музичному мистецтві грунтується на наукових працях з теорії семіотики різних наукових галузей та видів мистецтва: філософії (Ч. Пірс, К. Льюїс), культурології (В. Антонюк), літератури (Р. Барт, Ю. Лотман), психології (Ч. Морріс, Р. Якобсон), музикознавства (Л. Акопян, М. Арановський, М. Бонфельд, В. Москаленко, В. Холопова, С. Шип та інші). Однак методичний досвід реалізації семіотичного підходу у професійній підготовці майбутніх учителів музичного мистецтва до вокально-педагогічної діяльності потребує наукового усвідомлення та систематизації.

Mema cmammi- обгрунтувати теоретичні аспекти реалізації семіотичного підходу у професійній підготовці майбутніх учителів музичного мистецтва до вокально-педагогічної діяльності.

Завдання дослідження: здійснити аналіз науково-теоретичного досвіду щодо визначення базових понять дослідження; визначити особливості застосування семіотичного підходу у професійній підготовці майбутніх учителів музичного мистецтва до вокально-педагогічної діяльності.

Поняття «семіотика» у перекладі 3 грецької- учіння про знаки, наука про функціонування інформаційних знакових систем, за допомогою яких здійснюється спілкування в людському середовищі (природна мова, система мистецьких та 
наукових засобів передавання думок та почуттів тощо) [6, с. 589]. У наукових працях семіотичні терміни не отримали сталих трактувань. Термін «семіотика» ввів Дж. Локк ще у XVII столітті, однак виникнення семіотики як науки про знаки відноситься до кінця XIX - початку XX століття, що завдячується американському філософу Чарльзу Сендерсу Пірсу та швейцарському лінгвісту Фердинанду де Соссюру. Семіотика намагається створити мову для дослідження знаків незалежно від того, утворюють вони самі по собі мову, чи є вони знаками науки чи знаками мистецтва (Ч. Морріс). На думку Ю. Лотмана, і нам є близькою ця позиція, під семіотикою слід розуміти науку про комунікативні системи i знаки, які використовуються у процесі спілкування [4, с. 6].

Універсальним до виявлення художніх смислів мистецьких творів є семіотичний підхід, знання якого мають витоками філософію та лінгвістику. Він за своєю сутністю розглядається як використання лінгвістики музичної мови, лінгвістичного аналізу художнього тексту, вперше був застосований у музичному мистецтві на початку XX століття. За останне десятиліття XXI століття семіотичний підхід вийшов за межі філософії, лінгвістики та знайшов широке застосування в мистецтвознавстві, мистецькій педагогіці тощо. У творах мистецтва художні смисли надаються в закодованому вигляді. Водночас музика $є$ своєрідним феноменом, спорідненим 3 іншими видами мистецтв, виявляючи свою специфіку. Музична проблематика, до якої відноситься і проблема смислотворення, обов'язково пов'язана з семіотикою, тобто музичною знаковістю і структурою мови (В. Суханцева). Застосування семіотичного підходу надає змогу майбутнім фахівцям виявити особливості мови музичних творів, що сприяє розкодуванню художніх смислів.

Досліджуючи проблему тексту i закладених у ньому смислів 3 позиції семіотичного підходу, Ю. Лотман зазначав, що текст становлять механізм, утворений як система різнорідних семіотичних процесів, у континуумі яких циркулює певне вихідне повідомлення [5, с. 9]. Отже, науковець чітко окреслює, що в полі зору семіотики перебувають механізми утворення тексту,тоді як саме повідомлення, смисл, на наш погляд, є предметом дослідження герменевтики. Художній текст можна розглядати як механізм, сконструйований так, щоб міг діяти безпосередньо, тобто незалежно від рефлексивної свідомості читача (глядача, слухача). Проте призначення семантичного аналізу, вважає автор, полягає в тому, щоб такі структури віднайти i зрозуміти, як вони працюють. На відміну від літературного тексту в музиці структури дані безпосередньо в нотному тексті, а смисл стає об'єктом рефлексії (М. Арановський).

Вивчаючи феномен української вокальної школи в контексті етнокультурологічних проблем, В. Антонюк зазначила, що семіотичний підхід сприяє розумінню явищ національного вокального мистецтва як метакультурного феномену, а семіотичні аспекти мистецтва сольного співу $є$ важливими складниками його соціокультурної місії - поліфункційного діалогу індивідууму та суспільства [1]. На наш погляд, поняття «семіотичний підхід» у музичному мистецтві необхідно розглядати як метод системного дослідження мови музичного твору. У результаті його реалізації уможливлюється опанування майбутніми вчителями музичного мистецтва методами семіотичного аналізу музично-поетичного тексту, який є важливим компонентом моделі виконавського аналізу вокального твору, що впливає на інтелектуальне сприймання музики майбутніми учителями музичного мистецтва. У дисертації Я. Іваницької, предметом дослідження якої став вокальний жанр - оперна вистава як семіотичний об'єкт, зазначається, що донині точиться дискусія щодо можливості називати музику знаковим явищем, бо вона позбавлена предметної конкретності та властивого знаку 
співвідношення означення і означуваного (денотату та десигнату) [3]. Науковець зазначає, що з моменту написання музики утворюється перший нерозривний синтез, де композитор, $з$ одного боку, є втілювачем процесу перекодування 3 вербального висловлювання на музичне, з іншого, - творцем нового тексту.

Семіотичний підхід є системним дослідженням музичного мистецтва та, на наш погляд, теоретичною базою для розв'язання естетичних проблем професійної підготовки майбутнього фахівця музичного мистецтва за умови реалізації семіотичного підходу, зазначає М. Бонфельд. Близькою нам є думка науковця, який уважає, що будь-який музичний твір, подібний знаку мови, становить цілісне матеріально-ідеальне утворення, що містить у собі єдність значимого і значущого. Це свідчить про те, що звучання музичного твору пов'язується у свідомості слухача 3 певним тільки цьому твору притаманним комплексом понять, уявлень, емоцій (духовних сутностей), що відрізняються від самого звучання, але перебуває 3 ним у специфічній єдності, чим і забезпечується сприйняття музики як визначеного змістусмислу [2, с. 16]. Через дослідження музичної мови твору як виду художньої мови, що опосередковується на рівні субзнаків (морфем, елементів знаку, що мають широке поле потенційних знаків), у майбутніх фахівців формується континуальне музичне мислення (домінування безперервного потоку мислення, який сприяє готовому рішенню тих, хто сприймає твори мистецтва - важливо для будь-якої людини, у нетворчій діяльності така частина духовного світу не функціонує). На думку науковця, цілісний музичний твір утворює цілісний знак, у яком елементи залежать від цілого і навпаки - ціле залежить від елементів [2, с.47]. Автор передбачає в дослідженні всі три виміри семіотики: «семантику - тобто відношення знака (субзнака) і значення, синтактику - відношення, що виникають між знаками (чи елементами знаків), прагматику- відношення між знаками і тими, хто користується ними» [2, с. 74]. Тож завдяки теоретичним висновкам автора уможливлюється семіотична модель аналізу вокального твору з точки зору трикомпонентної моделі семіотики.

Урахування такої наукової думки у процесі здійснення виконавського аналізу вокального твору уможливлює поетапність і цілісність дослідження його музичної мови майбутніми вчителями музичного мистецтва. До специфіки реалізації семіотичного підходу у професійній підготовці майбутніх фахівців до вокальнопедагогічної діяльності необхідно віднести семіотичний аналіз музичного та поетичного тексту, що утворюють синергетичну єдність - мистецький твір.

Отже, на основі аналізу наукової літератури, висвітлюючи особливості реалізації семіотичного підходу окресленої нами проблеми, зробимо такі узагальнення:

- упровадження семіотичної моделі аналізу вокального твору 3 позиції трикомпонентної моделі семіотики сприяє поглибленому розумінню майбутніми фахівцями музичного мистецтва музичної знаковості і структури мови на основі єдності змісту і мови вокальних творів;

- зважаючи на те, що у полі зору семіотики перебувають механізми утворення тексту, важливими є знання: як такі структури віднайти та зрозуміти, як вони працюють;

- застосування семіотичної моделі аналізу вокального твору установлює нерозривний синтез композитора, поета та втілювача;

- семіотичний підхід надає змогу проаналізувати вокальний твір як синергетичну цілісність, що є завжди незавершеною.

\section{Література}

1. Антонюк В. Г. Феномен украинской вокальной школы в контексте 
этнокультурологических проблем: дис. ... доктора культурол. наук: 24.00.01 / Валентина Геніївна Антонюк. - М., 2001. - 428 с. 2. Бонфельд М. Ш. Музыка : Язык. Речь. Мышление. Опыт системного исследования музыкального искусства: [монография] / М. Ш. Бонфельд. - СПб. : Композитор Санкт-Петербург, 2006. - 648 с. 3. Іваницька Я. А. Оперна вистава як семіотичний об'єкт / Я. А. Іваницька: автореф. на здобуття наук. ступ. канд. мистецтвознавства: спеціальність 17.00.03 «Музичне мистецтво» / Я. А. Іваницька. - ., 2008. - 17 с. 4. Лотман Ю. М. Семиосфера / Ю. М. Лотман. - СПб: Искусство - СПБ, 2010. - 704 с. 5. Лотман Ю. М. Текст в тексте / Ю. Лотман // Труды по знаковым системам. - Тарту, 1981. - Вып. 15. 6. Сучасний словник-мінімум іншомовних слів/ уклали: О.Скопненко, Т. Цимбалюк. - К. : Довіра, 2008. -798 с.

УДК $331.361: 356.13$

Олена Павленко

\section{ПРОФЕСІЙНА ВЗАЕМОДІЯ У ПРОЦЕСІ ПІДГОТОВКИ ФАХІВЦІВ ЗОВНІШНЬОКОМЕРЦЙННОЇ ДІЯЛЬНОСТІ}

Павленко О. О. Професійна взаємодія у процесі підготовки фахівців зовнішньокомерційної діяльності.

У статті розглянуто актуальні питання професійної взаємодії у процесі професійної підготовки фахівців із зовнішньокомерційної діяльності в контексті глобалізації і стандартизації. Автор визначив важливість у 21 столітті професійної взаємодії, коли організації і їхні співробітники стикаються з проблемами, поставленими глобалізацією. Акцентується на необхідності та доцільності професійної взаємодії у процесі розробки й імплементації міжнародних професійних стандартів фахівців 3 зовнішньокомерційної діяльності як уніфікованого інструменту інституційного розвитку організацій в епоху глобалізації. Автором описано цілі і сутність професійної взаємодії у процесі підготовки фахівців зовнішньокомерційної діяльності.

Ключові слова: професійна взаємодія, професійна підготовка, фахівці 3 зовнішньокомерційної діяльності, професійні стандарти, глобалізація, інституційний розвиток.

Павленко Е. А. Профессиональное взаимодействие в процессе подготовки специалистов внешнекоммерческой деятельности.

В статье рассмотрены вопросы профессионального взаимодействия в процессе подготовки специалистов по внешнекоммерческой деятельности в контексте глобализации и стандартизации. Автор определил важность в 21 веке профессионального взаимодействия, когда организации и их сотрудники сталкиваются с проблемами, поставленными глобализацией. Делаются акценты на необходимости и целесообразности профессионального взаимодействия в процессе разработки и имплементации международных профессиональных стандартов специалистов по внешнекоммерческой деятельности как унифицированного инструмента институционального развития организаций в эпоху глобализации. Автором описаны цели и сущность профессионального взаимодействия в процессе подготовкиспециалистов по внешнекоммерческой деятельности.

Ключевые слова: профессиональное взаимодействие, профессиональная подготовка, специалисты по внешнекоммерческой деятельности, профессиональные стандарты, глобализация, институциональное развитие. 